\title{
Impacts of Large Amounts of Wind Power on Design and Operation of Power Systems; Results of IEA Collaboration
}

Conference Paper NREL/CP-500-43540 June 2008

B. Parsons and E. Ela National Renewable Energy Laboratory, USA

$\mathrm{H}$. Holttinen

VTT, Finland

P. Meibom

Riso DTU, Denmark

A. Orths

Energinet.dk, Denmark

M. O'Malley

University College Dublin, Ireland

B.C. Ummels

Delft University of Technology, the Netherlands

J.O. Tande

SINTEF, Norway

A. Estanqueiro

INETI, Portugal

E. Gomez

University Castilla la Mancha, Spain

J.C. Smith

UWIG, USA

To be presented at WindPower 2008

Houston, Texas

June 1-4, 2008 


\section{NOTICE}

The submitted manuscript has been offered by an employee of the Midwest Research Institute (MRI), a contractor of the US Government under Contract No. DE-AC36-99G010337. Accordingly, the US Government and MRI retain a nonexclusive royalty-free license to publish or reproduce the published form of this contribution, or allow others to do so, for US Government purposes.

This report was prepared as an account of work sponsored by an agency of the United States government. Neither the United States government nor any agency thereof, nor any of their employees, makes any warranty, express or implied, or assumes any legal liability or responsibility for the accuracy, completeness, or usefulness of any information, apparatus, product, or process disclosed, or represents that its use would not infringe privately owned rights. Reference herein to any specific commercial product, process, or service by trade name, trademark, manufacturer, or otherwise does not necessarily constitute or imply its endorsement, recommendation, or favoring by the United States government or any agency thereof. The views and opinions of authors expressed herein do not necessarily state or reflect those of the United States government or any agency thereof.

Available electronically at http://www.osti.gov/bridge

Available for a processing fee to U.S. Department of Energy and its contractors, in paper, from:

U.S. Department of Energy

Office of Scientific and Technical Information

P.O. Box 62

Oak Ridge, TN 37831-0062

phone: 865.576 .8401

fax: 865.576 .5728

email: mailto:reports@adonis.osti.gov

Available for sale to the public, in paper, from:

U.S. Department of Commerce

National Technical Information Service

5285 Port Royal Road

Springfield, VA 22161

phone: 800.553 .6847

fax: 703.605.6900

email: orders@ntis.fedworld.gov

online ordering: http://www.ntis.gov/ordering.htm 


\title{
Impacts of Large Amounts of Wind Power on Design and Operation of Power Systems; Results of IEA Collaboration
}

\author{
Hannele Holttinen $^{1 *}$, Peter Meibom ${ }^{2)}$, Antje Orths ${ }^{3)}$, Mark O’Malley ${ }^{4)}$, Bart C. Ummels ${ }^{5)}$, John Olav Tande ${ }^{6)}$, Ana Estanqueiro ${ }^{7)}$, \\ Emilio Gomez $^{8)}$, J. Charles Smith ${ }^{9)}$, Erik Ela ${ }^{10)}$ \\ 1) VTT, P.O. Box 1000, FI-02044 VTT, Finland. ${ }^{*}$ tlf. +358 20722 5798, e-mail hannele.holttinen $@$,vtt.fi \\ ${ }^{2)}$ Risø DTU, Denmark; ${ }^{3)}$ Energinet.dk, Denmark; ${ }^{4)}$ University College Dublin, Ireland; ${ }^{5)}$ Delft University of Technology, the Netherlands; \\ ${ }^{6}$ SINTEF, Norway; ${ }^{7)}$ INETI, Portugal; ${ }^{8)}$ University Castilla la Mancha, Spain; ${ }^{9)}$ UWIG, USA; ${ }^{10)}$ NREL, USA;
}

\begin{abstract}
There are a multitude of studies completed and ongoing related to the cost of wind integration. However, the results are not easy to compare. An international forum for exchange of knowledge of power system impacts of wind power has been formed under the IEA Implementing Agreement on Wind Energy. IEA WIND R\&D Task 25 on "Design and Operation of Power Systems with Large Amounts of Wind Power" produced a state-of-the-art report in October 2007, where the most relevant wind-power grid integration studies were analyzed, especially regarding methodologies and input data. This paper summarizes the results from 18 case studies, with discussion on differences in methodology as well as issues that have been identified to impact the cost of wind integration.
\end{abstract}

Index Terms - grid integration, wind power, power system operation, reserve requirements.

\section{Introduction}

The existing targets for wind power anticipate a quite high penetration of wind power in many countries. It is technically possible to integrate very large amounts of wind capacity in power systems, the limits arising from how much can be integrated at socially and economically acceptable costs.

Wind power production introduces more uncertainty in operating a power system; it is continuously variable and difficult to predict. To enable proper management of the uncertainty, there is need for more flexibility in the power system; either in generation, demand, or transmission between areas. How much extra flexibility is needed depends on the one hand on how much wind power capacity already has been installed in the respective region, and on the other hand, on how much flexibility already exists in the power system considered.

In recent years, several reports have been published in many countries investigating the power system impacts of wind generation. However, results of the costs of integration differ and comparisons are difficult to make due to different methodology, data, and tools used, as well as terminology and metrics in representing the results. An R\&D Task titled "Design and Operation of Power Systems with Large Amounts of Wind Power Production" has been formed within the "IEA Implementing Agreement on the Cooperation in the Research, Development and Deployment of Wind Turbine Systems" [1] in 2006 to collect and share information on the experience gained and the studies made, with analyses and guidelines on methodologies. The Task has started by producing a state-of-the-art report on the knowledge and results obtained so far and will end with developing guidelines on the recommended methodologies when estimating system impacts and costs of wind power integration. When possible, best practice recommendations will be formulated on system operation practices and planning methodologies for high wind penetration.

\section{Power System Impacts of Wind Power}

Wind power has impacts on power system operational security, reliability, and efficiency. The studies address different impacts, and the different time scales involved usually mean different models (and data) used in impact studies. Case studies for system wide impacts have been divided to three focus areas: Balancing, Adequacy of Power, and Grid (Fig 1). In this international collaboration (IEA WIND Task 25), more system-related issues are addressed, as opposed to local issues of grid connection like power quality. Primary reserve is here denoted for reserves activated in seconds (frequency activated reserve; regulation) and secondary reserve for reserves activated in $10 \ldots 15$ minutes (minute reserve; load following reserve).

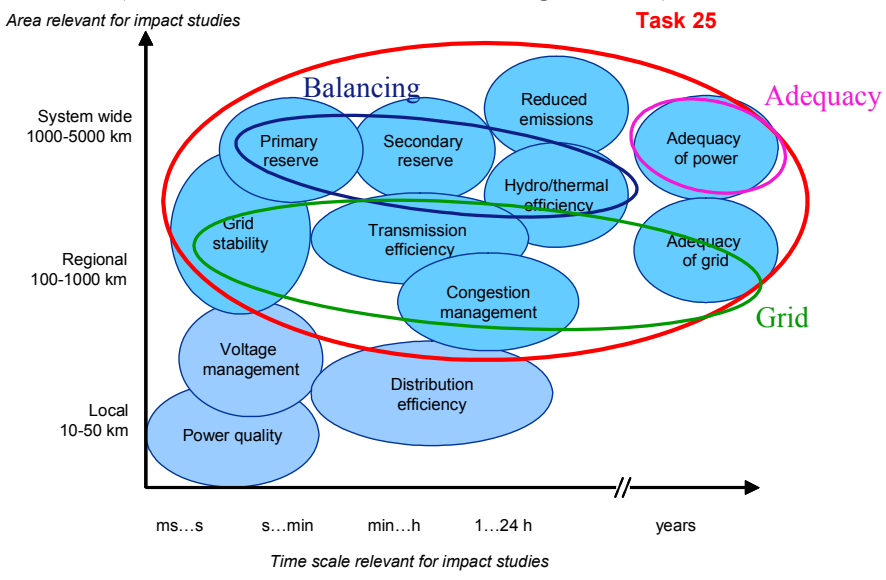

Figure 1. Impacts of wind power on power systems, divided in different time scales and width of area relevant to the studies.

Balancing: Increases needed in allocation and use of short-term reserves (time-scale minute...half an hour) and the impact of wind variability and prediction errors on efficiency and unit commitment of existing power capacity (time scale: hours...days). The uunpredicted part of the variations of large-area wind power should be combined with any other unpredicted variations the power system experiences, like unpredicted variations in load. Variability of wind power impacts on how the conventional capacity is run, and how the variations and prediction errors of wind power change the unit commitment. Analysing and developing methods of incorporating wind power into existing planning tools is important in order to account for wind power uncertainties and existing flexibilities in the system adequately. The simulation results give insight into the technical impacts of wind power, and also the (technical) costs involved. 
Adequacy of Power: Total supply available during peak load situations (time scale: several years, and associated with static conditions of the system). The estimation of required generation capacity needs includes the system load demand and maintenance needs of production units (reliability data). The criteria that are used for the adequacy evaluation include the loss of load expectation (LOLE), the loss of load probability (LOLP) and the loss of energy expectation (LOEE), for instance. The issue is the proper assessment of wind power's aggregate capacity credit in the relevant peak load situations - taking into account the effect of geographical dispersion and interconnection.

Grid: The impacts of wind power on transmission depend on the location of wind power plants relative to load, and the correlation between wind power production and electricity consumption. Wind power affects power flow in the network. It may change the power flow direction, and reduce or increase power losses and bottleneck situations. There are a variety of means to maximise the use of existing transmission lines like use of online information (temperature, loads), FACTS, and wind power-plant output control. However, grid reinforcement may be necessary to maintain transmission adequacy and security. When determining adequacy of the grid, both steady-state load flow and dynamic system-stability analysis are needed. Different wind turbine types have different control characteristics, and consequently, also have different possibilities to support the system in normal and system-fault situations. For system stability reasons, operation and control properties will be required from wind power plants at some stage, depending on wind power penetration and power system robustness.

\section{Summary of Case Studies Reviewed}

For the case studies reviewed in this paper, the emphasis is on more recent studies, and especially on those that have tried to quantify the power system impacts of wind power. A short description of the studies is given here, and a more detailed description is provided in [2], also listing on-going research. A summary table for the power systems and largest wind penetration studied is presented in Table 1 .

Greennet-EU27 [3] estimated increases in system operation costs as a result of increased shares of wind power for a 2010 power-system case covering Denmark, Finland, Germany, Norway, and Sweden combined with three wind cases. The integration costs of wind is calculated as the difference between the system operation costs in a model run (WILMAR) with stochastic wind power forecasts and the system operation costs in a model run where the wind power production is converted into an equivalent predictable, constant, wind power production during the week.

Operating reserve requirements due to wind power in the Nordic countries has been estimated in 2004 [4]; up to $4 \mathrm{GW}$ of wind in the 14-GW peak system of Finland, and up to 18 GW of wind in the 67-GW peak system of Nordic countries $(10-20 \%$ penetration). The methodology is the statistical method combining the standard deviations of wind and load variations time series, and four times standard deviation of the variations time series is used as confidence level $(4 \sigma)$. Three years of synchronous hourly time series for load and (up-scaled) wind power was used. The better predictability of load was taken into account applying load forecast errors instead of load time series. The cost estimates take into

Table 1. Data for power systems and wind power in case studies. The year for the power system-load scenario is marked after the region name (expect for Minnesota where the year refers to the study). Use of interconnection capacity is not taken into account in studies marked with *. In the Nordic 2004 study, interconnection capacity between the Nordic countries is taken into account, not the interconnection to outside Nordic area.

\begin{tabular}{|c|c|c|c|c|c|c|c|c|c|c|}
\hline \multirow{3}{*}{ Region / case study } & \multirow{2}{*}{\multicolumn{3}{|c|}{ Load }} & \multirow{3}{*}{$\begin{array}{l}\begin{array}{l}\text { Inter- } \\
\text { connect. } \\
\text { capacity }\end{array} \\
\text { MW }\end{array}$} & \multicolumn{6}{|c|}{ Wind power } \\
\hline & & & & & \multirow{2}{*}{$\begin{array}{l}2006 \\
\text { MW }\end{array}$} & \multicolumn{2}{|l|}{$\begin{array}{l}\text { Highest } \\
\text { studied }\end{array}$} & \multicolumn{3}{|c|}{ Highest penetration level } \\
\hline & $\begin{array}{l}\text { Peak } \\
\text { MW }\end{array}$ & $\begin{array}{l}\text { Min } \\
\text { MW }\end{array}$ & $\mathrm{TWh} / \mathrm{a}$ & & & MW & $\begin{array}{l}\text { TWh } \\
/ \mathrm{a}\end{array}$ & $\begin{array}{l}\% \text { of } \\
\text { peak } \\
\text { load }\end{array}$ & $\begin{array}{l}\% \text { of } \\
\text { gross } \\
\text { demand }\end{array}$ & $\begin{array}{l}\% \text { of (min } \\
\text { load + } \\
\text { interconn) }\end{array}$ \\
\hline Denmark 2025 & 7200 & 2600 & 38 & 5190 & 3125 & 6500 & 20.2 & $90 \%$ & $53 \%$ & $83 \%$ \\
\hline Nordic 2004/VTT & 67000 & 24000 & 385 & $3000 *$ & 4356 & 18000 & 46 & $27 \%$ & $12 \%$ & $67 \%$ \\
\hline Nordic + Germany/Greennet & 155500 & 65600 & 977 & 6600 & 26603 & 57500 & 115 & $37 \%$ & $12 \%$ & $80 \%$ \\
\hline Finland & 14800 & 5900 & 90 & $2280 *$ & 110 & 7300 & 16 & $52 \%$ & $18 \%$ & $89 \%$ \\
\hline Germany 2015 / DENA & 77955 & 41000 & 552.3 & $10000^{*}$ & 20622 & 36000 & 77.2 & $46 \%$ & $14 \%$ & $71 \%$ \\
\hline Ireland / ESBNG & 6500 & 2500 & 38.5 & 0 & 805 & 3500 & 10.5 & $54 \%$ & $27 \%$ & $140 \%$ \\
\hline Ireland / SEI & 6900 & 2455 & 39.7 & $900 *$ & 805 & 1950 & 5.1 & $28 \%$ & $13 \%$ & $58 \%$ \\
\hline Ireland /All island & 9600 & 3500 & 54 & 1000 & 900 & 6000 & 19 & $63 \%$ & $35 \%$ & $178 \%$ \\
\hline Netherlands & 25200 & 9000 & 127 & $7350 *$ & 1746 & 10000 & 35 & $40 \%$ & $28 \%$ & $61 \%$ \\
\hline Mid Norway /Sintef & 3780 & & 21 & & & 1062 & 3.2 & $28 \%$ & $15 \%$ & \\
\hline Portugal & 8800 & 4560 & 49.2 & $1000^{*}$ & 2150 & 5100 & 12.8 & $58 \%$ & $26 \%$ & $92 \%$ \\
\hline Spain 2011 & 53400 & 21500 & 246.2 & $2400 *$ & 15145 & 17500 & 46 & $33 \%$ & $19 \%$ & $73 \%$ \\
\hline Sweden & 26000 & 13000 & 140 & $9730 *$ & 788 & 8000 & 20 & $31 \%$ & $14 \%$ & $35 \%$ \\
\hline UK & 76000 & 24000 & 427 & $2000 *$ & 2389 & 38000 & 115 & $50 \%$ & $27 \%$ & $146 \%$ \\
\hline US Minnesota 2004 & 9933 & 3400 & 48.1 & $1500^{*}$ & 1300 & 1500 & 5.8 & $15 \%$ & $12 \%$ & $31 \%$ \\
\hline US Minnesota 2006 & 20000 & 8800 & 85 & & 1300 & 6000 & 21 & $30 \%$ & $25 \%$ & $68 \%$ \\
\hline US New York & 33000 & 12000 & 170 & 7000 & 430 & 3300 & 9.9 & $10 \%$ & $6 \%$ & $17 \%$ \\
\hline US Colorado & 7000 & & 36.3 & & & 1400 & 3.6 & $20 \%$ & $10 \%$ & \\
\hline US Pacificorp & 10000 & & & & & 2000 & & $20 \%$ & $8 \%$ & \\
\hline US California & 64300 & 25000 & 304 & & 2439 & 12500 & 34 & $19 \%$ & $11 \%$ & \\
\hline US Texas & 65200 & 16000 & 317 & & 4356 & 15000 & 54 & $23 \%$ & $17 \%$ & \\
\hline
\end{tabular}


account both new reserve capacity and the increased use of reserves. In 2008, the grid reinforcement needs and costs were evaluated in M.Sc thesis [5] for 2-7.3 GW of wind in Finland. The overall grid investments were estimated to 149 million $€$ for $2 \mathrm{GW}$ of wind (5\% penetration) and 394 million $€$ for $7.3 \mathrm{GW}$ of wind. This reduced wind related costs of 8 and 253 million $€$ when planned grid reinforcements were taken into account.

The Swedish additional reserve requirements of $4-8 \mathrm{GW}$ of wind $(7-13 \%$ penetration) for the $26-\mathrm{GW}$ peak system were estimated based on a similar approach of the Nordic 2004 study, combining the standard deviation of load and wind variation time series. Time scales used were for oneand four-hour forecast errors separately [6]. Several years of wind data was acquired based on meteorological data, and synchronous load forecast error data was also available. No cost estimates were made.

The Danish transmission system operator Energinet.dk has recently analyzed implications of the government's energy policy for 2025 of a doubling of wind power to about 6,500 MW by 2025 . The change corresponds to a future increase from $20 \%$ to about $50 \%$ of wind energy coverage in Denmark [7]. Further large-scale integration of wind power calls for exploiting both domestic flexibility and international power markets with measures on the market side, production side, transmission side, and demand side. Another study [8] focusing on the year 2030 with a slightly different grid structure compared to [7] concentrated on different options of grid expansion. The respective grid reinforcement costs with different options (cabling and overhead lines) results in a cost of 335 - 4906 million Euros for a 400-kV transmission grid, and a cost of 27 - 1542 million Euros for the $130-150$ $\mathrm{kV}$ transmission grid, reaching a total between 363 and 6448 million Euros. The reason for grid expansion is the installation of wind power facilities on the one hand and market requirements on the other hand.

The impact of wind power on system adequacy for one region in Norway [9] is assessed using data from a real life regional hydro-based power system with a predicted need for new generation and/or reinforcement of interconnections to meet future demand. Wind power will have a positive effect on system adequacy. Wind power contributes to reducing the LOLP and to improving the energy balance. Adding 3 TWh of wind or $3 \mathrm{TWh}$ of gas generation are found to contribute equally to the energy balance, both on a weekly and annual basis. Both wind and gas additions improve power balance. The capacity value of gas is found to be about $95 \%$ of rated, and the capacity value of wind about $30 \%$ at low wind energy penetration, and about $14 \%$ at $15 \%$ penetration. The smoothing effect due to geographical distribution of wind power has a significant impact on the wind capacity value at high penetration.

In the German Energy Agency's (DENA) study [10], the integration of a total of $36 \mathrm{GW}$ of wind power capacity into the German transmission system in 2015 was studied. According to this study, approximately $850 \mathrm{~km}$ of $380-\mathrm{kV}$ transmission routes, as well as reinforcement of $390 \mathrm{~km}$ of existing power lines will be needed. In addition, numerous $380-\mathrm{kV}$ installations will need to be fitted with new components for active power flow control and reactive power compensation (approximately 7,350 Mvar till 2015). Modification of the existing German Grid Code, for instance, in view of fault-ride-through and grid voltage control, was necessary. The capacity credit of wind power was estimated, as well as the additional requirement for reserves. The regulating and reserve power capacity required for the following day was determined in relation to the forecasted wind infeed level. The additionally required regulating energy could be provided by the existing conventional power stations, so no cost estimate for reserves was made.

The All Island Grid Study [11], commissioned by the government of the Republic of Ireland and Northern Ireland included a network study to quantify necessary transmission system upgrades, and a unit commitment and dispatch study. Within the modeling limitations of the study methodologies, the study found that up to $42 \%$ of energy from renewable sources (mainly wind) was feasible and that there would be additional costs on the order of $7 \%$ over a business-as-usual case. There was also significant $\mathrm{CO}_{2}$ reduction benefits $(25 \%)$ and security of supply benefits seen because of a reduction in fuel imports. The study highlighted the need for an appropriate plant mix with such high levels of renewables, and it also illustrated the significant impact of the operation of thermal plant and the need for substantial network reinforcement. The base portfolio was $2 \mathrm{GW}$ of wind (Ireland currently has $1 \mathrm{GW}$ ), and is taken as a business-as-usual case. Going to $6 \mathrm{GW}$ of wind installation, the operational costs fall by $€ 13 / \mathrm{MWh}$ when compared to the base case. Transmission costs (not annualised) are 915 million $€$ to go from the base case to $6 \mathrm{GW}$. Additional storage did not appear to bring additional benefits, although this needs further study. Improved forecasting did bring some modest benefits. The study also documented the need for further work and concluded that some additional costs were not captured. In previous work, the TSO ESBNG [12] made system simulations using a unit commitment and dispatch simulator. The study found that high wind-energy penetration greatly increased the number of start ups and ramping for gas turbine generation in the system, and that the cost of using wind power for $\mathrm{CO}_{2}$ abatement in the Irish electricity system is $€ 120 /$ Tonne. The capacity credit of wind power was estimated by assessing the amount of a conventional plant that is displaced, while keeping generation adequacy at the desired level. In the Irish SEI report [13], system simulations were made using a proprietary system dynamic model. Fuel cost and $\mathrm{CO}_{2}$ savings up to a $1500-\mathrm{MW}$ wind power penetration level in the Republic of Ireland (ROI) system were directly proportional to the wind energy penetration. It found that while wind did reduce overall system operation costs, it could lead to a small increase in operating reserve costs: 0.2 $€ / \mathrm{MWh}$ for $1300 \mathrm{MW}$ of wind and $0.5 € / \mathrm{MWh}$ for $1950 \mathrm{MW}$ of wind.

In the U.K., amounts for the increase in reserve requirements are estimated to be modest - around $5 \%$ of the wind plant capacity at the $20 \%$ penetration level ( $\%$ of gross demand). Estimates of extra reserve costs from [14] used market costs, which may be expected implicitly to include a capital recovery element. A value of $£ 2.38$ per MWh of wind produced for $10 \%$ wind penetration is used, rising to $£ 2.65 / \mathrm{MWh}$ at $15 \%$ and $£ 2.85 / \mathrm{MWh}$ at $20 \%$ penetration. Transmission costs will depend on how the wind power plants are distributed in the U.K.; if onshore wind generation were developed across Great Britain and included the offshore wind resources around the England and Wales coast, then transmission reinforcement costs could be significantly smaller than if wind power plants were developed mostly in Scotland and off the Northwest and 
Northeast coasts of England and North Wales. In [14], costs of between $£ 275$ and $£ 615$ million to accommodate $8 \mathrm{GW}$ of wind were estimated, i.e. between $£ 35 / \mathrm{kW}$ and $£ 77 / \mathrm{kW}$ were found. In [15], the effects of connecting wind power plants at various locations across the country was considered, as well as the impact of the locations of existing, new, and decommissioning conventional plants. The range of cost was found to be between $£ 1.7$ and $£ 3.3$ billion for $26 \mathrm{GW}$ of wind. Lower values correspond to scenarios with dispersed wind generation connections, while the higher values correspond to the scenarios with a considerable amount of wind being installed in Scotland and north of England. For a small level of wind penetration, the capacity value of wind is roughly equal to its load factor, or approximately $35 \%$. But as the capacity of wind generation increases, the marginal contribution declines. For a level of wind penetration of 26 $\mathrm{GW}$, about $5 \mathrm{GW}$ of conventional capacity could be displaced, giving a capacity credit of about $20 \%$ (for a future UK system of 70-GW peak load and a 400 TWh energy demand, and a $35 \%$ load factor of wind).

In the Netherlands, the consequences of $6000 \mathrm{MW}$ of offshore wind power for the $150 / 380-\mathrm{kV}$ grid were determined by a load flow study. This showed that additional voltage control equipment is required and that a limited number of lines have to be upgraded. Investment costs for the grid were estimated at $344-660$ million $€$, depending on location/scenario (about $4 \%$ of est. total investment for $6 \mathrm{GW}$ of wind) [16]. Research into the system integration of wind power has shown that minimum load problems, rather than the variability or partial unpredictability of large-scale wind power, can be foreseen as the bottleneck for system integration in the Netherlands [17]. Additional flexibility from conventional units or use of interconnection capacity will be required. System integration of future large-scale wind power in the Netherlands does not necessitate the development of energy storage, especially if international exchange is available [18]. Although energy storage provides significant opportunities for the reduction of total system costs, this comes at the expense of additional $\mathrm{CO}_{2}$ emissions at the system level, due to energy conversion losses inherent to energy storage, and the additional operation of baseload coal-fired plants at the expense of peak load gas-fired plants, the latter of which produce less $\mathrm{CO}_{2}$ on a MWh-basis [19].

For Portugal, in the overall period 2005 - 2010, the investment in the transmission grid directly attributable to renewables (mostly for wind parks) will total 200 million $€$. These numbers do not consider the investment of the wind park main substation nor the direct line to the transmission network connection point, which are built by the promoter. In studies carried out by Spanish and Portuguese TSOs REE and REN [20-21], wind power impacts on the grid were studied under different scenarios (demand, wind energy production, and different degrees of adaptation of new wind turbine and wind power plant technologies). Two scenarios were studied with 17,500 MW of installed wind power. With $75 \%$ of wind power technically adapted, transient stability was supported for $14,000 \mathrm{MW}$ wind power production in a peak demand scenario and 10,000 MW wind power production in a valley (i.e., time of low demand). The importance of the future $400-\mathrm{kV} \mathrm{D} / \mathrm{C}$ interconnection line with France was highlighted.

In the Spanish case, wind power development has imposed new connecting and operating rules for wind power plants. The transmission network updates of 2200 million $€$, not only attributable to renewables, has been estimated by REE for the overall period $2006-2010$. In terms of investments due to wind energy, it is difficult to obtain the figures since grid reinforcements and new lines are also needed due to electrical demand growth which has been high in recent years.

The first Minnesota Dept. of Commerce/Enernex Study (2004) [22] estimated the impact of wind in a 2010 scenario of $1500 \mathrm{MW}$ of wind in a 10-GW peak load system. Threeyear data sets of 10-minute power profiles from atmospheric modeling were used to capture geographic diversity. Wind plant output forecasting was incorporated into the next day schedule for unit commitment. Extensive time-synchronized historic utility load and generator data was available. A monopoly market structure, with no operating practice modification or change in conventional generation expansion plan, was assumed. Incremental regulation due to wind was found to be $8 \mathrm{MW}$ (at $3 \sigma$ confidence level). Incremental intra-hour load following burden increased $1-2 \mathrm{MW} / \mathrm{min}$. (negligible cost). Hourly to daily wind variation and forecasting error impacts are the largest cost items. A total integration cost of $\$ 4.60 / \mathrm{MWh}$ was found, with $\$ 0.23 / \mathrm{MWh}$ representing increased regulation costs, and $\$ 4.37$ due to increased costs in the unit commitment time frame. A capacity credit of $26 \%-34 \%$ was found with a range of assumptions using the ELCC method.

The second Minnesota Dept. of Commerce/EnerNerx study (2006) [23] took as a subject power system a consolidation of four main balancing areas into a single balancing area for control performance purposes. Simulations investigating $15 \%, 20 \%$, and $25 \%$ wind energy penetration of the Minnesota balancing-area retail load in 2020 were conducted. The 2020 system peak load was estimated at $20,000 \mathrm{MW}$, and the installed wind capacity was $5700 \mathrm{MW}$ for the $25 \%$ wind energy case. Three years of high resolution wind and load data were used in the study. The cost of wind integration ranged from a low of $\$ 2.11 / \mathrm{MWh}$ of wind generation for $15 \%$ wind penetration in one year to a high of $\$ 4.41 / \mathrm{MWh}$ of wind generation for $25 \%$ wind penetration in another year, compared to the same energy delivered in firm, flat blocks on a daily basis. These are total costs and include both the cost of additional reserves, and cost of variability and day-ahead forecast errors associated with wind generation. The cost of the additional reserves attributable to wind generation is included in the wind integration cost. Special hourly runs were made to isolate this cost, which was found to be about $\$ 0.11 / \mathrm{MWh}$ of wind energy at the $20 \%$ penetration level. The remainder of the cost is related to how the variability and uncertainty of wind generation affects unit commitment and market operation. In the study, the Minnesota balancing authority was assigned responsibility for all the reserves and intra-hour resources for balancing. At the hourly level, the day-ahead markets and inthe-day re-dispatch at the hourly level were administered by MISO for the entire footprint, with an assumed 2020 peak load in excess of $120 \mathrm{GW}$. Since the real-time market actually operates on five-minute increments, further efficiencies could be obtained if it were assumed that out-ofstate resources were available to balance within the hour. Capacity values were investigated and ranged between $5 \%$ and $20 \%$ for the scenarios studied.

The NYSERDA/GE Energy Study for the New York ISO [24] estimated the impact of wind in a 2008 scenario of 3300 MW of wind in a 33-GW peak load system. Wind power 
profiles from atmospheric modeling were used to capture statewide diversity. The study used the competitive market structure of the NYISO for ancillary services, which allows determination of generator and consumer payment impacts. For transmission, only limited delivery issues were found. Post-fault grid stability improved with modern turbines using doubly-fed induction generators with vector controls. Incremental regulation requirements due to wind were found to be $36 \mathrm{MW}$. No additional spinning reserve was needed. Incremental intra-hour load following burden increased $1-2$ $\mathrm{MW} / 5$ minutes. Hourly ramp increased from $858 \mathrm{MW}$ to 910 MW. All increased needs can be met by existing New York resources and market processes. The capacity credit was $10 \%$ average onshore and $36 \%$ offshore. Significant system cost savings of $\$ 335$ - $\$ 455$ million for assumed 2008 natural gas prices of $\$ 6.50-\$ 6.80 / \mathrm{MMBTU}$ were found.

The Xcel Colorado/Enernex Study (2006) [25] examined $10 \%$ and $15 \%$ penetration cases (wind nameplate to peak load) in detail for a roughly 7-GW peak load system. Regulation impact was $\$ 0.20 / \mathrm{MWh}$ and hourly analysis gave a cost range of $\$ 2.20-\$ 3.30 / \mathrm{MWh}$. This study also examined the impact of variability and uncertainty on the dispatch of the gas system, which supplies fuel to more than $50 \%$ of the system capacity. Additional costs of $\$ 1.25-$ $\$ 1.45 / \mathrm{MWh}$ were found for the $10 \%$ and $15 \%$ cases, bringing the total integration costs to the $\$ 3.70-\$ 5.00 / \mathrm{MWh}$ range for the $10 \%$ and $15 \%$ penetration cases.

The California RPS Integration Cost Project [26] examined impacts of existing installed renewables (wind at $4 \%$ on a capacity basis). Regulation cost for wind was $\$ 0.46 / \mathrm{MWh}$. Load following had minimal impact. A wind capacity credit of $23 \%-25 \%$ of a benchmark gas unit was found. The Intermittency Analysis Project in [27] studied three different scenarios: $7500 \mathrm{MW}$ and 12,500 MW of wind power for year $201064-\mathrm{GW}$ peak load system (20 and 33\% total renewable capacity penetration) and $12,700 \mathrm{MW}$ for year 2020 81-GW peak load system (33\% total renewable capacity penetration). The study recommended significant increases in transmission infrastructure. For 2010, the scenario accelerated 72 new or upgraded line segments equalling $\$ 1.2$ billion. For the 2020 scenario, $\$ 5.7$ billion in transmission upgrades was recommended. The California ISO added to this study with their results on integration impacts [28] - the ISO reported an extremely large increase in regulation capacity, which is due to assumptions on forecast errors by persistence. The report showed that existing generation resources would be able to account for the required increases in regulation and load following capacity in normal operation conditions, but that it is possible during low hydro periods (and because of the reliance on slower moving thermal units), that the ISO may need to commit additional capacity for the required regulation.

In Texas, the ERCOT/GE study [29] looked at penetrations of up to $15,000 \mathrm{MW}$ of wind power in a $65-\mathrm{GW}$ peak load system. Using a 98.8th percentile for changes in regulation requirements with wind, the study reported about a $54 \mathrm{MW}$ and $48 \mathrm{MW}$ increase in up regulation and down regulation, respectively. The load following time-scale was not studied in detail. Interestingly in this study, the cost of regulation per $\mathrm{MWh}$ of wind using a state-of-the-art wind forecast increases as wind capacity reaches $10,000 \mathrm{MW}$ up to $\$ 0.27 / \mathrm{MWh}$, but then decreases to an actual savings of regulation payments costs at the 15,000 MW penetration level. The reason for this is that even with the higher regulation requirements, the regulation clearing prices for the ancillary service market decrease as the unit commitment problem is solving to commit cheaper units because of the added wind capacity. Therefore, the lost opportunity costs for regulation decrease, as do payments for regulation as $\$ / \mathrm{MWh}$ regulation decrease. This conclusion hasn't been seen in any other integration study. Wind generation also decreases the total energy cost on the system to about $\$ 55 / \mathrm{MWh}$ of wind energy due to a decrease in energy prices.

\section{Summary of Results on Increased Balancing Requirements}

Summaries for the results for balancing requirements presented in section 3 are presented in Figures 2 and 3.

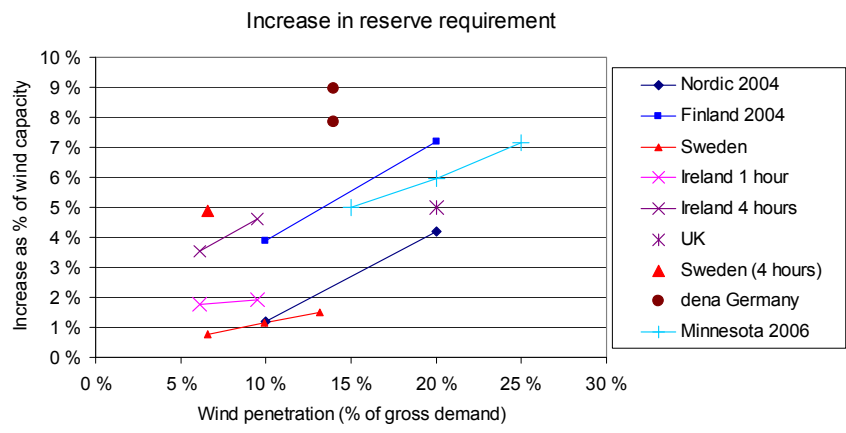

Figure 2. Results for the increase in reserve requirement due to wind power. The German DENA estimates take into account the dayahead uncertainty (for up and down reserves separately). In Minnesota, day ahead uncertainty has been included in the forecast. For the others, the effect of variations during the operating hour is considered. For the U.K., Ireland, and Sweden, the 4-hour ahead uncertainty has been evaluated separately.

The increase in reserve requirements is mostly estimated by statistical methods combining the variability of wind power to that of load. In some studies, the sudden outages of production are also combined into reserve requirements (disturbance or contingency reserve). For the impact on operation of power systems, model runs are made and most results are based on comparing costs of system operation without wind and adding different amounts of wind. The costs of variability are also addressed by comparing simulations with flat wind energy to varying wind energy (for example, in U.S. Minnesota and Greennet Nordic+Germany).

The increase in the short-term reserve requirement has been estimated to less than $4 \%$ of installed wind capacity with low penetration ( $<10 \%$ of gross demand) and for hourly variability of wind, to about $5 \%$ for forecast errors for 4 hours ahead, and to nearly $10 \%$ if day-ahead forecast errors are left to be balanced with the short-term reserves.

At wind penetrations of up to $20 \%$ of gross demand, system operating cost increases arising from wind variability and uncertainty amounted to about $1-4 € / \mathrm{MWh}$. This is $10 \%$ or less of the wholesale value of the wind energy. It can be seen that there is considerable scatter in results for different countries and regions. 


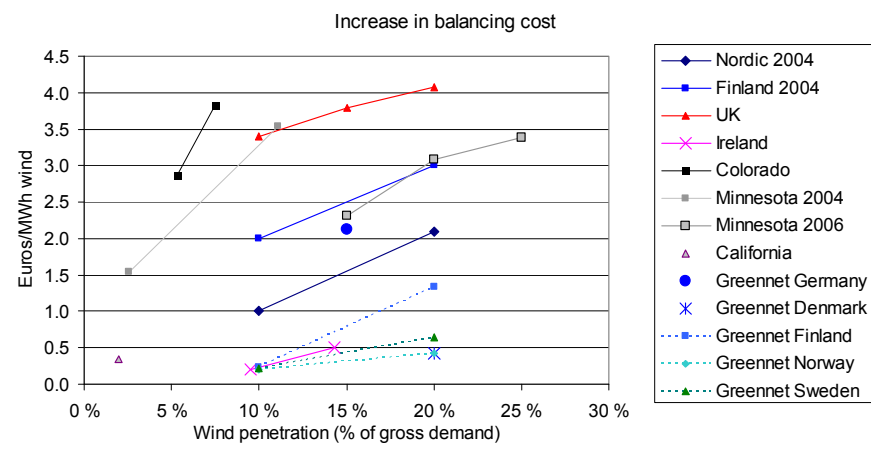

Figure 3. Results from estimates for the increase in balancing and operating costs due to wind power. The currency conversion used here is $1 €=0.7 £$ and $1 €=1.3$ U.S. $\$$.

The following differences have been noted:

- Different time scales used for estimating - For the U.K., the increased variability to 4 hours ahead has been taken into account. For U.S. studies, the unit commitment impact for day-ahead scheduling is also incorporated. For the Nordic countries and Ireland, only the increased variability during the operating hour has been estimated. For the Greennet study, the unit commitment and reserve allocation are done according to wind forecasts, but the system makes use of updated forecasts 3 hours before delivery for adjusting the production levels.

- Costs for new reserve capacity investment - For the Greennet and SEI Ireland studies, only incremental increase in operating costs have been estimated, whereas investments for new reserves are also included in some results (Nordic 2004).

- Larger balancing areas - The Greennet, Minnesota 2006, and Nordic 2004 studies incorporate the possibilities for reducing operation costs through power exchange to neighboring countries, whereas Colorado, California, German DENA, Swedish, U.K., and Ireland studies analyze the country in question without taking transmission possibilities into account. The two studies for Minnesota show the benefit of larger markets in providing balancing. The same can be seen from the Nordic 2004 results compared with results calculated for Finland alone. Dealing with large wind-output variations and steep ramps over a short period of time could be challenging for smaller balancing areas. Larger power systems make it possible for smoothing of the wind variability.

As shown in Table 1, the interconnection capacity to neighboring systems is often significant. For balancing costs, it is essential whether the interconnection capacity can be used for balancing purposes or not in the study setup. A general conclusion is that if interconnection capacity is also allowed to be used for balancing purposes, then the balancing costs are lower compared to if they are not allowed to be used. From the first methodology review, the other important factors identified as reducing integration costs were aggregating wind plant output over large geographical regions, and operating the power system closer to the delivery hour.

The recently published Irish All Island Grid Study going from 2 to $6 \mathrm{GW}$ of wind showed that the operational costs fall by $€ 13 / \mathrm{MWh}$ when compared to the base case - due to the cost benefit approach in the study, the cost component was not published as such.

\section{Summary of Grid Results}

With current technology, wind power plants can be designed to meet industry expectations such as riding through voltage dips, supplying reactive power to the system, controlling terminal voltage, and participating in SCADA system operation with output and ramp rate control. In areas with limited penetration, system stability studies have shown that modern wind plants equipped with power electronic controls and dynamic voltage support capability can improve system performance by damping power swings and supporting postfault voltage recovery. The results of the studies performed in Spain and Portugal suggest that at higher penetration levels, requiring sufficient fault ride-through capability for large wind power plants would be economically efficient.

Grid reinforcements may be needed for handling larger power flows and maintaining a stable voltage, and are commonly needed if new generation is installed in weak grids far from load centers. The issue is generally the same, be it modern wind power plants or any other power plants. The cost of grid reinforcements due to wind power is therefore very dependent on where the wind power plants are located relative to the load and grid infrastructure, and one must expect numbers to vary from country to country. It is also important to note that grid reinforcements in general should be held up against the option of curtailing wind or altering operation of other generation, and these latter options may in some cases prove to be very cost efficient.

For grid reinforcement, the reported results in the national case studies are:

- U.K.: $£ 65$ - $125 / \mathrm{kW}(85-162 € / \mathrm{kW})$ for $26 \mathrm{GW}$ of wind $(20 \%$ energy penetration) and $£ 35 / \mathrm{kW}-£ 77 / \mathrm{kW}$ for $8 \mathrm{GW}$ of wind.

- Netherlands: $60-110 € / \mathrm{kW}$ for $6 \mathrm{GW}$ of offshore wind.

- Portugal: from $53 € / \mathrm{kW}$ (only summing the proportion related to the wind program of total cost of each grid development or reinforcement) to around $100 € / \mathrm{kW}$ (adding total costs of all grid development items) for $5.1 \mathrm{GW}$ of wind.

- German DENA study: $100 € / \mathrm{kW}$ for $36 \mathrm{GW}$ of wind.

- Finland 2008: $54 € / \mathrm{kW}$ for $7.3 \mathrm{GW}$ of wind. If the grid will be reinforced due to other needs, assumed extra costs for wind power are $35 € / \mathrm{kW}$.

- Ireland, 2008: The grid investments are $228 €$ per $\mathrm{kW}$ for the additional $4 \mathrm{GW}$ to reach $6 \mathrm{GW}$, or $153 € / \mathrm{kW}$ allocated for all of the $6 \mathrm{GW}$ of wind.

- In Denmark there is a large range for future grid investments depending on whether cabling or overhead lines are used $(53-994 € / \mathrm{kW})$. This cost is not all attributable to wind power.

The cost of grid reinforcement needs due to wind power cannot be directly compared; they will vary from country to country largely depending on location of the wind power plants relative to load centers. The grid reinforcement costs are not continuous; there can be single, very high cost reinforcements. There can also be differences in how the costs are allocated to wind power; for example, in Portugal, it has been evaluated how much of the new lines are due to wind power, and only that part of the costs have been allocated to wind. 


\section{Summary of Adequacy/Capacity Credit Results}

The capacity credit of wind power answers questions like: Can wind substitute for other generation in the system and to what extent? Is the system capable of meeting a higher (peak) demand if wind power is added to the system?

Wind generation will provide some additional load carrying capability to meet expected, projected increases in system demand. This contribution can be up to $40 \%$ of installed wind power capacity (in situations with low penetration and high capacity factor at times of peak load), and down to $5 \%$ in higher penetrations or if regional wind power output profiles correlate negatively with the system load profile.

Results for the capacity credit of wind power are summarized in Figure 4. Results of capacity credit calculations show a considerable spread. One reason for different resulting levels arises from the wind regime at the wind power plant sites. For zero penetration level, all capacity credit values are in the range of the capacity factor of the evaluated wind power plant installations. This is one explanation for low German capacity-credit results shown in Figure 4 . The correlation of wind and load is very beneficial, as can be seen in Figure 4 in the case of the New York offshore capacity credit being $40 \%$.

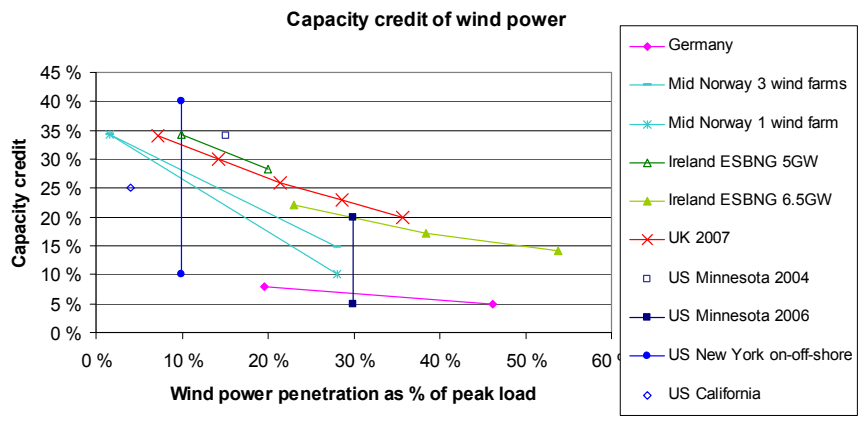

Figure 4. Capacity credit of wind power; results from national studies.

The wind capacity credit in percent of installed wind capacity is reduced at higher wind penetration levels, but also depends greatly on the geographical smoothing. This is demonstrated when comparing the cases of mid-Norway with 1 and 3 wind power plants. In essence, it means that the wind capacity credit of all installed wind in Europe or the United States is likely to be higher than those of the individual countries or regions, even if the total penetration level is as in the individual countries or regions. Indeed, this is true only when assuming that the grid is not limiting the use of wind capacity, i.e., just as available grid capacity is a precondition for allocating the capacity credit to other generation.

\section{Conclusions and Discussion}

High penetration of wind power has impacts that have to be managed through proper plant interconnection, integration, transmission planning, and system and market operations. Integration costs can be divided into different components arising from the increase in the operational balancing cost and grid expansion cost. The value of the capacity credit of wind power can also be stated. The case studies summarized in this paper are not easy to compare due to the different methodologies and data used, as well as different assumptions on the availability of interconnection capacity.

From the investigated studies, system operating cost increases amounted to about $1-4 € / \mathrm{MWh}$. This is $10 \%$ or less of the wholesale value of the wind energy. There is also a benefit when adding wind power to power systems; it reduces the total operating costs and emissions as wind replaces fossil fuels. The increase in the short-term reserve requirement has been estimated to be less than $4 \%$ of installed wind capacity with low penetration $(<10 \%$ of gross demand), and for hourly variability of wind, to about $5 \%$ for forecast errors for 4 hours ahead, and to nearly $10 \%$ if dayahead forecast errors are left to be balanced with the short term reserves.

The cost of grid reinforcements due to wind power is dependent on where the wind power plants are located relative to load and grid infrastructure. The grid reinforcement costs from investigated studies varied from 35 $€ / \mathrm{kW}$ to $160 € / \mathrm{kW}$. The grid reinforcement costs are not continuous; there can be single, very high cost reinforcements. Also, there can be differences in how the costs are allocated to wind power. It is also important to note that grid reinforcements in general should be held up against the option of curtailing wind or altering operation of other generation, and optimized use of the transmission network can also postpone grid investments. However, when planning for large wind power additions to the system, grid reinforcements and extensions are usually required, and making the grid reinforcements directly to the foreseen wind amounts in the future will in most cases be more cost effective than building the grid in phases. With current technology, wind power plants can be designed to ride through voltage dips and participate in voltage and frequency control.

The capacity value of wind power can be up to $40 \%$ of installed capacity if wind power production at times of high load is high, and down to $5 \%$ in higher penetrations and if local wind characteristics correlate negatively with the system load profile. Aggregating larger areas benefits the capacity value of wind power.

Several issues that impact on the amount of wind power that can be integrated have been identified. Large balancing areas and aggregation benefits of large areas help in reducing the variability and forecast errors of wind power, as well as help in pooling more cost effective balancing resources. System operation and working electricity markets at less than day-ahead time scales help reduce forecast errors of wind power. Transmission is the key to aggregation benefits, electricity markets, and larger balancing areas.

Integration costs of wind power need to be compared to something meaningful, like the production costs or market value of wind power, or integration cost of other production forms. There is also benefit when adding wind power to power systems; it reduces the total operating costs and emissions as wind replaces fossil fuels. Indeed, the benefits are expected to be significantly higher than the costs. Taking fuel savings only, these will be roughly proportional with the wind generation, and a magnitude higher than the foreseen cost of balancing. In this summary, only the cost component has been analyzed.

For high penetration levels of wind power, the optimization of the integrated system should be explored. Modifications to system configuration and operational practices to accommodate high wind penetration may be required. For high penetrations, there will be need for increased generation flexibility, transmission to neighboring areas, demand side management, or storage (e.g., pumped hydro, thermal, or batteries of electric cars). Wind power 
integration should be assessed at the international level to identify the needs and benefits of interconnection of national power systems.

\section{References}

1. http://www.ieawind.org/AnnexXXV.html

2. Holttinen, H, Lemström, B, Meibom, P, Bindner, H, Orths, A, Van Hulle, F, Ensslin, C, Tiedemann, A, Hofmann, L, Winter, W, Tuohy, A, O'Malley, M, Smith, P, Pierik, J, Tande, J O, Estanqueiro, A, Gomez, E, Söder, L, Strbac, G, Shakoor, A, Smith, J C, Parsons, P, Milligan, M, Wan, Y. Design and Operation of Power Systems with Large Amounts of Wind Power. State-of-theart report. VTT Working Papers 82, 2007. VTT, Espoo, Finland. Available at http://www.vtt.fi/inf/pdf/workingpapers/2007/W82.pdf.

3. Meibom, P., Weber, C., Barth, R., Brand, H., Operational costs induced by fluctuating wind power production in Germany and Scandinavia, pp 133-154, In: Swider, D., Voss, A. (Eds), Deliverable D5b - Disaggregated system operation cost and grid extension cost caused by intermittent RES-E grid integration, GreenNet-EU27, 2006. http://greennet.i-generation.at/

4. Holttinen, H, 2005. Impact of hourly wind power variations on the system operation in the Nordic countries. Wind Energy, vol. 8, 2, ss. $197-218$.

5. Lamponen, J. Master's Thesis for Helsinki Technical University (in Finnish). Main results can be found in: Lamponen, J, Haarla, L, Matilainen, J, Koskinen, M, Lemström, B. Wind power, grid reinforcement needs and connection issues. Proceedings of EWEC'2008, 31.3.-3.4.2008, Brussels, Belgium.

6. Axelsson U, Murray R, Neimane V, $4000 \mathrm{MW}$ wind power in Sweden - Impact on regulation and reserve requirements. Elforsk Report 05:19, Stockholm, 2005. http://www.elforsk.se

7. Energinet.dk. Systemplan 2007. www.energinet.dk

8. Electricity Infrastructure Committee, 2008. Technical Report on the future expansion and undergrounding of the electricity transmission grid. Summary. April 2008. Available at www.energinet.dk

9. Tande $\mathrm{J} \mathrm{O}$, Korpås $\mathrm{M}$, Impact of large scale wind power on system adequacy in a regional hydro-based power system with weak interconnections. Nordic Wind Power Conference Hanasaari, Finland, 22-23 ${ }^{\text {rd }}$ May, 2006

10. DENA, 2005. Planning of the grid integration of wind energy in Germany onshore and offshore up to the year 2020 (DENA Grid study). Deutsche Energie-Agentur Dena, March 2005.

11. All Island Grid Study, www.dcenr.gov.ie, 2008.

12. ESB National Grid, Impact of wind power generation in Ireland on the operation of conventional plant and the economic implications, February 2004.

13. SEI: Operating reserve requirements as wind power penetration increases in the Irish electricity system. Sustainable Energy Ireland, 2004

14. National Grid submission for the UK energy white paper, 2003.

15. Ilex Energy, Strbac, G, 2002. Quantifying the system costs of additional renewables in 2020. DTI, 2002. http://www.dti.gov.uk/energy/developep/080scar_report_v2_0.pdf

16. H.F. Eleveld, J.H.R. Enslin, J.F. Groema, K.J. van Oeveren, M.A.W. van Schaik: Connect 6000 MW-II, Elektrische infrastructuur op Zee. 2005, Kema 40510025-TDC-05-48500

17. B.C. Ummels, M. Gibescu, E. Pelgrum, W.L. Kling, A.J. Brand: Impacts of Wind Power on Thermal Generation Unit Commitment and Dispatch, IEEE Transactions on Energy Conversion, vol. 22, issue 1, March 2007, pp. 44-51
18. B.C. Ummels, E. Pelgrum, W.L. Kling, H. Droog: Energy Storage Options for System Integration of Offshore Wind Power in the Netherlands, EWEC 2008, Brussels, Belgium, 31 March-3 April, 2008, 10 pp.

19. B.C. Ummels, E. Pelgrum, W.L. Kling: Integration of LargeScale Wind Power and Use of Energy Storage in the Netherlands' Electricity Supply, IET Renewable Power Generation, vol. 2, issue 1, March 2008, pp. 34-46

20. Estudio de Estabilidad Eólica de la Península Ibérica - Síntesis de Criterios y Metodologías, REE / REN. May, 2005.

21. Rodríguez-Bobada, F; Reis Rodriguez, A; Ceña, A; Giraut, E, Study of wind energy penetration in the Iberian peninsula. European Wind Energy Conference (EWEC), 27 February - 2 March, 2006, Athens, Greece

22. Xcel North study (Minnesota Department of Commerce), EnerNex/Windlogics. http://www.state.mn.us/cgi-bin/portal/mn/jsp/ content. do contentid $=536904447 \&$ contenttype $=$ EDITORIAL \&hpa ge $=$ true\&agency $=$ Commerce

23. Enernex, 2006. Final Report - 2006 Minnesota Wind Integration Study. Available at http://www.uwig.org/opimpactsdocs.html

24. General Electric and AWS Scientific/TrueWind solutions: New York State ERDA study. http://www.nyserda.org/rps/draftwindreport.pdf

25. Zavadil, R, 2006. "Wind Integration Study for Public Service Company of Colorado", May 22, 2006. available at http://www.xcelenergy.com/XLWEB/CDA/0,3080,1-1$1 \quad 1875 \quad 15056 \quad 15473-13518-2 \quad 171$ 258-0,00.html

26. Shiu, H., Milligan, M., Kirby \& B. Jackson, K. 2006. California Renewables Portfolio Standard Renewable Generation Integration Cost Analysis. California Energy Commission, PIER Public Interest Energy Research Programme. Available at http://www.energy.ca.gov/pier/final_project reports/CEC-5002006-064.html

27. Intermittency Analysis Team, 2007. Intermittency Analysis Project: Final Report", July 2007 http://www.energy.ca.gov/pier/final_project_reports/CEC-5002007-081.html

28. California ISO/GE "Integration of Renewable Resources", July 2007. http://www.caiso.com/1ca5/1ca5a7a026270.pdf

29. GE/ERCOT "Draft Final Report: Analysis of Wind Generation Impact on ERCOT Ancillary Services Requirements", $\quad$ March 2008. http://www.ercot.com/calendar/2008/02/20080227-WIND.html 


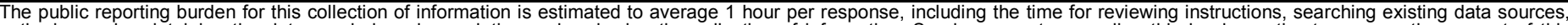

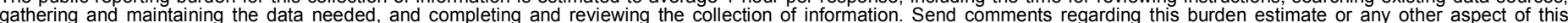

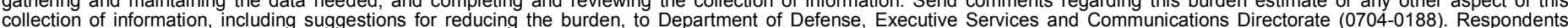

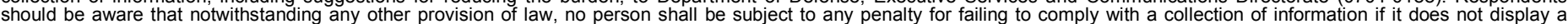

should be aware that notwithstanding

PLEASE DO NOT RETURN YOUR FORM TO THE ABOVE ORGANIZATION.

\begin{tabular}{l|l|l|l} 
1. REPORT DATE $(D D-M M-Y Y Y Y)$ & 2. & REPORT TYPE & 3. DATES COVERED (FrOm - TO)
\end{tabular}

June 2008

Conference Paper

4. TITLE AND SUBTITLE

Impacts of Large Amounts of Wind Power on Design and Operation

of Power Systems; Results of IEA Collaboration

6. AUTHOR(S)

Brian Parsons, Erik Ela,Hannele Holttinen, Peter Meibom, Antje

Orths, Mark O'Malley, Bart C. Ummels, John Olav Tande, Ana

Estanqueiro, Emilio Gomez, and J. Charles Smith. 5a. CONTRACT NUMBER

DE-AC36-99-GO10337

5b. GRANT NUMBER

5c. PROGRAM ELEMENT NUMBER

5d. PROJECT NUMBER

NREL/CP-500-43540

5e. TASK NUMBER

WER8.5001

5f. WORK UNIT NUMBER
7. PERFORMING ORGANIZATION NAME(S) AND ADDRESS(ES)

National Renewable Energy Laboratory

1617 Cole Blvd.

Golden, CO 80401-3393
8. PERFORMING ORGANIZATION REPORT NUMBER

NREL/CP-500-43540

9. SPONSORING/MONITORING AGENCY NAME(S) AND ADDRESS(ES)

10. SPONSOR/MONITOR'S ACRONYM(S) NREL

11. SPONSORING/MONITORING AGENCY REPORT NUMBER

12. DISTRIBUTION AVAILABILITY STATEMENT

National Technical Information Service

U.S. Department of Commerce

5285 Port Royal Road

Springfield, VA 22161

13. SUPPLEMENTARY NOTES

14. ABSTRACT (Maximum 200 Words)

This paper summarizes the results from 18 case studies, with discussion on differences in methodology as well as issues that have been identified to impact the cost of wind integration.

15. SUBJECT TERMS

Wind; integration; wind power; reserve requirements; power system operation; wind integration; grid integration; electric utilities; IEA; Task 25; Europe

\begin{tabular}{|c|c|c|c|c|}
\hline \multicolumn{3}{|c|}{ 16. SECURITY CLASSIFICATION OF: } & \multirow{2}{*}{$\begin{array}{l}\text { 17. LIMITATION } \\
\text { OF ABSTRACT } \\
\text { UL }\end{array}$} & \multirow{2}{*}{$\begin{array}{ll}\text { 18. } & \text { NUMBER } \\
\text { OF PAGES }\end{array}$} \\
\hline $\begin{array}{l}\text { a. REPORT } \\
\text { Unclassified }\end{array}$ & $\begin{array}{l}\text { b. ABSTRACT } \\
\text { Unclassified }\end{array}$ & $\begin{array}{l}\text { c. THIS PAGE } \\
\text { Unclassified }\end{array}$ & & \\
\hline
\end{tabular}

19a. NAME OF RESPONSIBLE PERSON

19b. TELEPHONE NUMBER (Include area code) 